\title{
PENELITIAN TINDAKAN PARTISIPATORIS DALAM BIDANG PSIKOLOGI SOSIAL
}

\author{
Fattah Hanurawan \\ Universitas Negeri Malang
}

\section{INTISARI}

Tulisan in bermaksud mendeskripsikan secara kritis model penelitian tindakan partisipatoris dalam bidang psikologi sosial. Penelitian tindakan partisipatoris adalah salah satu model penelitian kritis yang dirancang untuk dapat secara langsung memecahkan suatu masalah dan dapat diterapkan secara langsung ke dalam setting suatu penelitian berlangsung. Tujuan pembaharuan, pemberdayaan kolektit, dan kesadaran diri merupakan prinsip utama penelitian tindakan pantisipatoris yang dapat dicapai melalui penelitian secara langsung dan reficksi partisipan bersama fasilitasi peneliti. Secara umum penelitian tindakan partisipatoris sangat sesuai untuk memecahkan masalah-masalah psikologi sosial.

Kata kunci: Penelitian tindakan partisipatoris, psikologi sosial.

\begin{abstract}
Fiattah Hanurawan adalah dosen di Universitas Negeri Malang. Penulis lahir di Malang, 6 Oktober 1966. Lulus St Filsafat UGM (1988); lulus MSi Psikologi Sosial Universitas indonesia, Jakanta (1993); lulus Master of Education dalam Pendidikan Sosial Deakin University, Melbourne Aus. tralia (1996); Saat Ini adalah mahasiswa program Doktor Fakultas Psikologi UGM dengan kekhususan Psikologi Sosial (Angkatan 1998). Telah menulis lebih dari 15 tulisan ilmiah pada Jurnal Ilmlah lokal maupun nasional (terakreditasi).
\end{abstract}

PSIKOLOGIKA Nomor 11 Tahun VI 2001

\section{PENDAHULUAN}

D alam erkembangan ilmu psikologi sampai saat ini, terdapat idealisme untuk mempersatukan teori psikologi yang bersifat akademis dengan praktek-praktek yang bermanfaat bagi kehidupan sehari-hari. idealisme itu sesuai dengan pernyataan -filosofis keilmuan yang dikemukakan pakar filsalat instrumentalisme Amerika Serikat, John Dewey. la berpendapat bahwa suatu teori ilmiah dapat dinilai tidak memiliki makna yang signifikan apabila tidak memiliki manfaat langsung bagi kehidupan manusia. Menurut Dewey (dalam Ellias \& Meriam, 1980), suatu teori dapat diklasifikasikan sebagai teori yang baik apabila mampu mewujudkan esensi dirinya ke dalam penerapan hidup kemanusiaan secara langsung. 
Dalam konteks idealisme kesatuan teori dan praktis, model penelitian tindakan partisipatoris dapat dilihat sebagai suatu gambaran rancangan penelitian yang berupaya memenuhi kebutuhan dan tuntutan itu. Pada kesempatan ini akan dicoba dideskripsikan secara kritis penerapan model penelitian tindakan partisipatoris $d$ dalam bidang penelitian psikologi sosial.

\section{PENDEKATAN ALTERNATIF DALAM PENELITIAN PSIKOLOGI}

Gelombang perkembangan gerakan filsafat yang disebut Postmodernisme atau Postpositivistik telah banyak memberi pengaruh dalam pemikiran dan gaya hid up manusia yang hidup pada era revolusi informasi awal milenium ketiga ini. Pengaruh gerakan filsafat itu pada akhirnya juga berdampakdalam dunia penelitian ilmu-ilmu sosial, termasuk di dalamnya adalah bidang iimu psikologi (Denzin \& Lincoln, 1994). Pengaruh dalam bidang penelitian ilmu psikologi itu tampak dari usaha-usaha untuk mengajukan alternatif-alternatif pendekatan baru dalam metode penelitian psikologi.

Alternatif-alternatif baru itu terutama muncul dari ketidakpuasan sebagian ilmuwan psikologi terhadap paradigma positivistik yang telah lama menjadi pendekatan utama dalam penelitian psikologi. Dalam hal ini, paradigma positivistik dianggap terlalu menekankan penelitian. psikologl pada wilayah penelitian labo. ratorium, desain eksperimental, dan analisis statistik. Apabila diamati secara lebih cermat, nampak bahwa paradigma positivistik yang menekankan aspek kuantitatif pada bidang penelitian psikologi berupaya untuk menerapkan prinsip-prinsip epistemologis penelitian ilmu kealaman ke dalam ilmu psikologi. Pendekatan positivistik dipandang kurang memberi tempat pada pilihan-pilihan, kebebasan, individualitas, dan tanggung jawab sosial yang terdapat dalam diri manusia yang menjadi objek kajian psikologi (Cohen \& Manion, 1981).

Ketidakpuasan terhadap paradigma positivistik, dalam perkembangan berikutnya, memuncutkan kebutuhan untuk menemukan metode-metode baru yang dapat melengkapi keterbatasan pendekatan positivistik. Penemuan metode-metode baru itu didasarkan pada beberapa prinsip dasar yang menjadi semacam pengarah bagi usaha pembaruan metodologis. Smith, Harre, dan Langenhove (1995) mengajukan prinsip-prinsip itu sebagai berikut: Pertama, bahwa penelitian psikologi seharusnya dilakukan dalam setting kehldupan nyata atau yang bersifat alamiah. Kedua, adanya pengakuan terhadap peran utama bahasa dan diskursus dalam konstruksi gejala-gejala psikologis. Kerlga, kehidupan manusia dan penelitian dipahaml sebagal kegiatan yang berlangsung sebagai suatu proses timbal balik atau sebagai suału kegiatan yang berlangsung secara interaktit dan dinamis. Keempat, lebih tertarik pada gejala psikologis yang bersifat personal dan individual, daripada gejala-gejala yang diukur dalam bentuk variabel dan yang melibatkan subjek dengan jumlah kelompok besar.

Berdasar beberapa prínsip d atas terlihat bahwa penekanan penelitian psikologis mulai lebih ditekankan pada aspek refleksi terhadap kedekatannya dengan kehidupan psikologis yang bersifat individual. Selain itu, metode penelitian psikologi baru juga mulai mengakui kedudukan bahasa sebagai pembentuk konstruksi realitas psikologis manusia.

Sebagai konsekuensidari penekanan pada sifat individual dan pengakuan terhadap pentingnya arti bahasa sebagai pembentuk realitas psikologis, tidak mengherankan apabila sebagian besar metode yang tercakup dalam paradigma baru itu lebih bersifa! kualitatif ketimbang 
kuantitatif. Secara metodologis, usaha untuk menggali makna yang terkandung dalam perilaku subjektif manusia individual memang lebih tepat dengan menggunakan pendekatan penelitian ideografis yang ber. sifat interpretif kualitatif. Pendekatan penelitian ideografis berusaha menangkap kekayaan dan kompleksitas gejala melalui populasi-populasi yang berlingkup terbatas (Uzzell, 1995).

Pada konteks ini. pengembangan metode interpretif kualitatif terhadap gejalagejala kemanusiaan telah lama dilakukan oleh ahli antropologi, sosiologi, dan pendidikan, dalam usaha untuk menggali fenomena penelitian yang bersifat ideografis dan Khas kemanusiaan. Berdasar pada dua prinsip itu maka merupakan suatu hal yang logis dalam ilmu psikologi ideografis untuk mencoba mendeskripsikan gejala perilaku unik tertentu pada diri manusia melalui penggunaan pendekatan metodologis kualitatif (Uzzell, 1995).

Dalam paradigma baru penelitian psikologi iu terdapa: berbagai model penelitian, metode pengumpulan data, dan teknik analisis yang ditawarkan. Beberapa model penelitian utama dalam penelitian kualitatif yang dapat diintroduksi dalam penelitian psikologi adalah model fenomenologi, interaksionisme simbolik, studi kasus, penelitian lapangan, etnogyrafi dan tindakan. Metodemetode pengümpulan data itu adalah catatan lapangan, wawancara mendalam, observasi partisipasi, dan catatan cerita hidup. Teknik analisis yang ditawarkan adalah analisis isi, analisis fenomenologis, analisis tematik, dan analisis naratif (Connole, 1993; Smith, Harre \& Langenhove, 1995).

Pada kesempatan ini akan dicoba uraikan salah satu model yang secara metodologis dipandang dapat memberi kontribusi baru bagi pengembangan ilmu psikologi yang bersifat lebih humanistik dan dapat diterapkan secara langsung dalam kehidupan nyata. Model itu adalah model tindakan partisipatoris (paticipatory action research) yang lebih dahulu berkembang luas dalam penelifian pendidikan dan ilmuilmu sosial lain pada sekitar awal tahun 1980an. Model ini dapat dikatakan bersifat humanistik karena secara kualitatif dalam proses penelitian yang bersifal interaktif partisipatif melibatkan subjek penelitian sekaligus sebagai rekan-peneliti (co-researchen.

\section{PENELITIAN TINDAKAN PAFTISIPATORIS SEBAGAI PENELITIAN KRITIS}

Sebenarnya perkembangan luas penelitian tindakan partisipatoris tidak dapat dilepaskan dari pengaruh gerakan filsafat kritis yang muncul pada sekitar akhir tahun 1960an d Eropa Barat. Secara Umum, dasar-dasar pemikiran model penelitian tindakan-partisipatoris dapat ditelusuri kembali le dalam unsur-unsur pemikiran dari filsafat kritis. Tujuan filsafat kritis adalah mengarahkan manusia untuk dapat beremansipasi secara sadar dalam menjalani hidup, terlepas dari kungkungan hegemoni struktur sosial budaya yang mengkonstruksi dunia pemikiran manusia individual. Berdasar asumsi filsafat kritis itu, kegiatan penelitian seharusnya tidak sekedar bertujuan memberi deskripsi terhadap suatu situasi atau kondisi sosial kebudayaan. tetapi lebih jauh lagi sampai pada pemikiran kritis dan pada akhirnya sampai pada pemecahan masalah atau usaha-usaha pemberdayaan sebagai hasil dari tindakan emansipatif.

Menurut pendekatan kritis, salah satu kelemahan penting yang terdapat dalam penelitian positivistik adalah terlalu terbatasnya cakupan tujuan penelitian, yaitu sekedar pada deskripsi atau penjelasan tentang suatu gejala. Tujuan semacam itu 
dianggap tidak memadai karena kurang memperhatikan suatu kenyataan bahwa dalam realitas sosial terdapat banyak faktor struktur ekstemal yang memberi pengaruh dan membentuk tindakan orang-orang yang berinteraksi d dalamnya. Melalui penekanan pata deskripsi, kontrol, atau eksplanasi perilaku manusia, peneliti positivistik menjadi kurang memberi tempat bagi hubungan yang terjadi di antara deskripsi-deskripsi subjektif seseorang, tindakan seseorang, dan faktorfaktor eksternal yang memberi pengaruhdan membentuk pemikiran seseorang (Candy, 1989).

Pemahaman mendalam terhadap faktorfaktor eksternal sebenarnya merupakan suatu hal yang penting, karena faktor-faktor itu sering menguasai diri seseorang, sehingga ia tidak mampu untuk berpikir secara kritis dan bebas berdasar perspektif kesadaran pribadinya. Para pakar teori kritis utama yang berasal dari aliran FrankfurtJerman, mengemukakan bahwa faktorfaktoreksternal yang "menutupi" kesajaran kritis manusia antara lain adalah indoktrinasi ideologi, kepentingan politik, ekonomi, dan sosial kelompok hegemonik tertentu (Elliot, 1996). Dalam kerangka itu, tujuan penelitian kritis terutama adalah untuk dapat memahami dan membuka kendala-kendala eksternal yang membelengu dan menguasai cara berpikir individu-individu. Melalui pemahaman dan pemberdayaan itu diharapkan individu-individu itu sebagai pribadi dapat secara kritis dan sadar beremansipasi membentuk kerangka pemikiran sendiri untuk secara bersama mencapai perubahan masyarakat yang lebih seimbang, baik dari aspek sosial, politik, ekonomi, budaya, teknologi, maupun pendidikan (Smith \& Speedy, 1993).

Dapat disimpulkan secara filosofis, bahwa pendekatan kritis dalari penelitian memiliki visi terhadap perubahan sosial dan reformasi politik, serta asurnsi dasar bahwa seluruh kegiatan ilmiah, termasuk kegiatan penelitian, tidak bebas dari persoalan-persoalan etika, moral, sosial, dan politik. Pendekatan kritis dalam penelitian memiliki tujuan pada sekaligus arah transformasi personal maupun sosial, ketimbang hanya peda sekedar "deskripsi" yang bersifat ilmiah seperti pada pendekatan positivistik (Candy, 1989).

Sebagai salah satu varian dari pendekatan penelitian yang bersifat kritis, penelitian tindakan partisipatoris menentang kekuatan-kekuatan hegemonik yang menguasai, mendikte, dan mengatur pengetahuan dalam kehidupan masyarakat. Para pakar penelitian tindakan partisipatoris berupaya untuk menempatkan kembali hakhak setiap individu untuk menciptakan dan mendayagunakan pengetahuan berdasar pada pengalaman pribadi seseorang. Dal am konteks itu, penelitian tindakan partisipatoris berpretensi untuk menciptakan kesadaran sosial dalam masyarakat mela!ui proses swa-inkuiri dan swa-refleksi (Reason \& Heron, 1995).

\section{PENELITIAN TINDAKAN PARTISIPATORIS DALAM PSIKOLOGI SOSIAL}

\section{Penelitian Tindakan Partislpatoris sebagai} Instrumen Pembaharuan Sosial

Penelitian tindakan partisipatoris adalah salah satu model penelitian kritis yang dirancang untuk dapat secara langsung mernecahkan suatu masalah dan dapat diterapkan secara langsung ke dalam settingsuatu penelitian berlangsung (Cohen \& Manion, 1989). Penelitian tindakan partisipatoris bertujuan untuk melakukan intervensi praktis terhadap suatu masalah yang dihadapi oleh kelompok sasaran dalam konteks sosial nyata untuk mencapai tujuluan pembaharuan sosial (Cohen \& Manion, 1981). Penelitian tindakan partisipatoris adalah suatu jenis penelitian sosial terapan 
yang berbeda dari jenis-jenis penelitian sosial lain, karena ciri keterlibatan peneliti secara bersama dengan partisipan-partisipan penelitian dalam tindakan langsung memecahkan masalah di kancah penelitian (Uzzell, 1995).

Berbeda dengan ragam penelitian konvensional yang merujuk terdapatnya jarak di antara peneliti dan subjek penelitian, dalam penelitian tindakan partisipatoris tidak terdapat jarak yang jelas di antara peneliti dan subjek (Hanurawan, 1998). Nampak bahwa pada proses penelitian, si peneliti berpindah dari peran pengamat menjadi seorang agen perubahan masyarakat (an agent of social change). Para pelopor penelitian tindakan partisipatoris berpendapat bahwa dalam pelaksanaan penelitian seharusnya secara inklusit terdapat di dalamnya usaha pengambilan tindakan pemecahan masalah, karena keduanya memiliki keterkaitan yang sangat erat. Hubungan d antara keduanya dapat dianalogikan seperti dua sisi dalam sekeping mata uang.

Selain dalam bidang psikologi, khususnya psikologi sosial dan industri, rancangan penelitian tindakan partisipatoris telah secara luas diterapkan dalam bidang kajian ilmu-ilmu sosial lain dan ilmu pendidikan. Bidang-bidang itu adalah kebijakan publik, manajemen organisasi, dan kebijakan pengembangan masyarakat (Uzzeli, 1995).

\section{Proses Penelltian}

Pengembang pertama penelitian tindakan partisipatoris, pakar psikologi sosial Kurt Lewin (dalam McTaggart, 1989; Uzzel, 1995), menggambarkan model penelitian ini sebagai suatu siklus kegiatan berkelanjutan yang berjalan secara spiral. Pada setiap tahap terdapat di dalamnya dinamika unsur-unsur pokok penelitian tindakan partisipatoris, yaitu identifikasi masalah, perencanaan, tindakan, dan evaluasi terhadap hasil tindakan tersebut.
Proses penelitian dimulai dengan latar belakang pemikiran umum tentang kebutuhan akan perubahan atau pengembangan oleh angggota-anggota kelompok partisipan yang sekaligus bertindak sebagai peneliti. Betelah melalui proses diskusi, kelompok partisipan penelitian itu dapat mengajukan identifikasi terhadap serangkaian masalah yang menjadi pokok perhatian dan minat bersama (Mc Taggart 1989).

Tahap permulaan itu, kemudian dilanjutkan dengan usaha bersama di antara anggota kelompok untuk melakukan tindakan perbaikan terhadap masalah-masalah melalui perencanaan tindakan yang mungkin dapat dilakukan. Tahap berikutnya adalah mencoba untuk melakukan penerapan terhadap perencanaan yang telah disetujui bersama itu. Pada proses penerapan itu kemudian diikuti dengan melakukan pengamatan terhadap hasil-hasil dari usaha penerapan itu di lapangan.

Tahap selanjutnya dilakukan penilaian melalui refleksi tehadap hasil-hasil usaha penerapan yang diperoleh melalui pengamatan. Kelemahan dan kelebihan dari konsekuensi-konsekuensi yang terdapat pada penerapan ditinjau kembali secara bersama oleh anggota-anggota kelompok partisipan penelitian, untuk kemudian dimulai siklus kedua penelitian yang ditandai dengan tahap perencanaan kembali (ro-planning), dilanj. thtkan dengan penerapan lanjut, pengamatan lanjut, refleksi lanjut, dan bila perlu dilakukan siklus tahap ketiga, dan seterusnya, sebagai suatu proses yang berkelanjutan (Smith \& Speedy, 1993). Batas akhir siklus dalam penelitian tindakan partisipatoris sangat bersifat relatif, terutama bergantung pada tercapainya tujuan perbaikan dan pemberdayaan oleh clan untuk anggota-anggota kelompok penelitian.

Secara umum penelitian tindakan partisipatoris dapat dilihat sebagai aplikasi metode ilmiah dalam pemecahan masaiah 
sosial nyata dengan keunikan adanya saling keterlibatan di antara peneliti di satu pihak dan anggota-anggota kelompok partisipan pada sisi yang lain (Aguinis, 1994). Dapat disimpulkan bahwa tujuan pembaharuan, pemberdayaan kolektif, dan kesadaran diri merupakan prinsip utarna penelitian tindakan partisipatoris yang dicapai melalui penelitian secara langsung dan refieksi partisipan bersama fasilitasi peneliti.

\section{Penelitlan Tindakan Partisipatoris dalam Bidang-bidang Psikoiogi Sosiai}

Dalam penelaahan masalah-masalah sosial, seperti masalah penanganan propaganda, amuk massa, perubahan sikap, dan persepsi lingkungan suatu masyarakat terhadap akibat-akibat kerusakan lingkungan, penanggulangan krisis sosial mendesak yang melibatkan aspek perilaku, para ahli psikologi sosial dapat mendayagunakan pendekatan penelitian tindakan partisipatoris sebagai salah satu instrumen pemecahan masalah. Dalam penanganan masalah-masalah sosial itu, penelitian tindakan dapat diwujudkan dalam berbagai bentuk kegiatan langsung, mencakup pendidikan dan latihan, penawaran fasilitasi, dan penyajian informasi sehingga membuat target partisipan yang sedang menghadapi masalah dapat mengambil keputusan mandiri berdasar pada pengetahuan dan kesadaran tentang berbagai alternatif pemecahan masalah.

Pada konteks pemecahan masalah sosial yang sedang terjadi dalam suatu masyarakat, seorang peneliti tindakan partisipatoris secara langsung merupakan bagian tidak terpisahkan dari proses pengambilan keputusan. Dengan demikian dapal dilihat bahwa melalui pengalaman berbagi dengan partisipan berdasar masalah yang sedang dihadapi, maka peneliti bersama partisipan dapat merekomendasikan bagi mereka suatu pemecahan masalah.
Pada konteks ini, kebenaran intersubjektif hasil penelitian tindakan partisipatoris dapat dilihat secara langsung mendapat penguatan atau penolakan dari masyarakat sasaran. Proses komunikasi hasil penelitian semacam itu sangat langka dijumpai pada jenis-jenis penelitian lain yang bersifat konvensional akademis (Uzzel, 1995).

Secara kongkret penelitian tindakan partisipatoris dalam bidang-bidang psikologi sosial dapat dicontohkan melalui topik usaha-usaha perubahan sikap dan perubahan perilaku lingkungan suatu kelompok masyarakat yang menempati daerah kumuh ke arah sikap dan perilaku yang lebih pro lingkungan.

Tahap pertama penelitian dimulai dengan tahap identifikasi masalah oleh anggota-anggota kelompok masyarakat sebagai partisipan bersama peneliti tentang faktor utama terjadinya kekumuhan di lingkungan mereka. Melalui proses diskusi kritis dan pengumpulan data awal, maka kelompok partisipan dapat menyimpulkan bahwa kekumuhan lingkungan mereka disebabkan oleh sikap dan perilaku penghuni yang kurang pro lingkungan. Mengaçu pada latar belakang kesimpulan awal itu kemudian dapat dirumuskan beberapa masalah yang relevan, seperti: "Bagaimanakah cara mengubah sikap masyarakat agar lebih memperhatikan kebersihan dan kelestarian lingkungan?" atau "Bagaimanakah cara mengubah perilaku masyarakat agar lebih memperhatikan kebersihan dan kelestarian lingkungan?" Tujuan kegiatan penelitian inl adalah untuk mencapai keberhasilan pernberdayaan dan perubahan masyarakat untuk memiliki sikap dan perilaku pro lingkungan yang lebilh memadai.

Tahap kedua penelitian adalah tahap perencanaan tindakan untuk merubah sikap dan perilaku masyarakat agar lebih pro lingkungan. Pada tahap ini dapat diajukan hipotesis berdasarpengumpulan data awal 
dan studi kerangka teoretik, intervensi dan modifikasi perilaku yang diperlukan bagi pembaharuan masyarakat. Hipotesis itu misalnya adalah: "Strategi pendidikan lingkungan melalui penyuluh lingkungan dapat memberikan perubahan positif bagi sikap dan perilaku pro lingkungan masyarakat" atau "Prinsip modifikasi perilaku behavioristik dan modeling teori belajar sosial dapat memberi pengaruh bagi pengembangan masyarakat menuju sikap dan perilaku pro lingkungan yang lebih positif".

Proses perencanaan tu kemudian dilikuti dengan tahap penerapan strategi-strategi yang diasumsikan dapat memberi pengaruh bagi pemberdayaan masyarakat agar menjadi lebih sadar lingkungan. Penerapan strategi itu secara simultan dilkuti dengan observasi terhadap hasil-hasil perubahan yang mungkin terjadi. Pada tahap ini beberapa metode pengumpulan data yang bersifat kualitatif dapat digunakan dalam kerangka observasi ${ }_{r}$ seperti wawancara mendalam atau triangulasi (Banister et.al., 1994).

Pada tahap berikutnya dilakukan penilaian terhadap hasil-hasil yang telah dicapai selama penerapan di lapangan. Dalam kegiatan penilaian ini, diskusi reflektif yang mendalam dilakukan oleh partisipan penelitian yang sekaligus juga menjadi rekan peneliti dan si peneliti sendiri. Apabila hasil tindakan sudah dianggap memadai maka penelitian itu dianggap telah mencapai akhir yang final. Sebaliknya, jika hasii penelitian dianggap belum memadai, maka kemudian dilakukan siklus penelitian tindakan partisipatoris yang kedua, demikian seterusnya sampai dicapai hasi tindakan yang dianggap memadai.

\section{PENUTUP: SEEUAH REFLEKSI KRITIS}

Berdasar pada deskripsi tentang penerapan penelitian tindakan partisipatoris dalam bidang psikologi secara umum dan bidang psikologi sosial secara khusus, dapat diajukan beberapa butir refleksi kritis berkenaan dengan deskripsi itu. Refleksi kritis itu terutama sejauh berhubungan dengan perbedaan yang mungkin terdapat di antara penelitian tindakan partisipatoris dan pendekatan penelitian yang bersifat konvensional.

Butir-butir refleksi kritis itu adalah: Butir pertama, melalui penelitian tindakan partisipatoris subjek yang menjadi partisipan penelitian tidak hanya mendapat manfaat teoritis dari hasil penelitian, namun lebih jauh lagi dapat memperoleh manfaat langsung berupa konsekuensi praktis yang menyentuh wilayah hidupnya. Proses komunikasi manfaat penelitian yang bersifat timbal balik itu mungkin terjadi karena dalam hal ini peneliti yang sekaligus menjadi anggota kelompok suatu komunitas masyarakat sosial memil iki kedudukan sepadan dengan anggota kelompok komunitas yang lain. Melalui kondisi hubungan sosial harmonis itu, sangat dimungkinkan untuk terjadi perubahan-perubahan yang dibutuhkan dalam masyarakat. Hal itu terjadi juga karena anggota suatu kelompok komunitas merasa bahwa perubahan itu berasal dari inisiatif mereka sendiri.

Butir kedua, penelitian tindakan partisipatoris bersifat partisipatif dan kolaboratif. Berdasar pada kedua ciri itu dapat dilihat bahwa penelitian tindakan partisipatoris merupakan jenis penelitian yang langsung melibatkan keiikutsertaan dan kerja sama segenap anggota suatu kelompok komunitas sasaran. Pada konteks ini peneliti tidak membuat distansi dengan partisipan maupun masalah-masalah yang sedang diteriti, melainkan mencoba "lebur" di dalamnya untuk secara bersama mencari pemecahan masalah kelompok sasaran. Peneliti maupun partisipan penelitian berupaya mencapai tahap emansipatif berkenaan dengan proses kesadaran berpikir 
kritis terhadap masalah yang sedang dihadapi.

Butir ketiga adalah penelitian tindakan partisipatoris termasuk jenis penelitian yang menekankan pada orientasi berpikir kritis untuk mencapai tujuan tindakan langsung yang relevan dengan masalah yang sedang dihadapi.

Butir keempat adalah bahwa ditinjau dari sudut filsafat ilmu, tujuan penelitian tindakan partisipatoris untuk mencapai pemecahan masalah langsung di dalam kancah masyarakat menggambarkan kaitan yang tepat dengan asumsi aksiologis ilmu-ilmu sosial yang tidak bebas nilai. Berbeda dengan penelitian di bidang ilmu alam yang sering kali menampakkan kecenderungan bebas nilai (value free) karena keinginan untuk mencapai tujuan objektivitas keilmuan empirik, penelitian tindakan partisipatoris sebagai bagian dari pendekatan penelitian yang bersifat ideografis mencoba membangun kesadaran manusia bahwa penelitian sebagai bagian dari aktivitas ilmu harus mengacu pada tujuan kesejahteraan manusia, Kesejahteraan manusia itu baik yang bersifat material maupun spiritual.

Demikianlah, ilmu psikologi sebagai bagian dari rumpun uas ilmu-ilmu sosial dapat memanfatkan ragam metode penelitian ini untuk mencapai tujuan normatif psikologi bagi pembentukan wacana antara teori.dan praktis dalam arah yang lebih seimbang. Keeratan timbal balik teori dan praktis melalui penelitian tindakan-partisipatoris sejalan dengan idealisme pengembang pertama ragam penelitian ini, Kurt Lewin. Beliau mengemukakan bahwa ilmu psikologi sebagai bagian dari ilmu-ilmu sosial harus dapat memberi arahan bagi tindakan sosial yang membumi (Aguinis, 1994). $\square$

\section{DAFTAR PUSTAKA}

Aguinis, H. 1993. Action Research and Scientific Method: Presumes Discrepancies and Actual Similarities. Journal of Applied Behavioural Scjence, 29, 416 431.

Banister, P., Burman, E., Parker, I., Taylor, M., \& Tindall, C, 1994. Qualitative Methods in Psychology: A Research Guide. Buckingham, Philadelphia: Open University Press.

Candy, P.C. 1989. Alternative Paradigms in Educational Research. Australian Educational Researcher, 16, 1-10.

Cohen, L. \& Manion, L. 1981. Perspectives on Classrooms and Schools. London: Holt Rinehart and Winston.

Cohen, L. \& Manion, L. 1989. Research Methods in Education. London: Routledge.

Connole, H. C. 1993. Issues and Methods in Research. Dalam H.C. Connole, B. Smith, R. Wiseman, R. (E ds). Research Methodology. Issues and Methods in Research. Geelong: Deakin University.

Denzin, N.K. \& Lincoln, Y.S. 1994. Introduction: Entering the Field of Qualitative Research. Dalam N.K. Denzin \& Y.S. Lincoln (Eds.) Handbook of Qualitative Research. Thousand Oaks, C.A. Sage Publications.

Elias, J.L. dan Merriam, S. 1980. Philosophical Foundations of Adult Education. Malabar, Florida: Krieger Publishing Company.

Elliot, A 1996. Psychoanalysis and Social Theory. Dalam B.S. Turner (Ed.) The Blackwell Companion to Social Theory. Oxford: Blackwell. 
Hanurawan, F. 1998. Pendekatan Positivistic, interpretif, dan Kritis dalam Penelitian Pendidikan. Forum Penelitian Kependidikan. Jurnal Teori dan Priatik Penelitian Kependidikan, 10, 3-16.

Mc Taggart, R. 1989. Principle for Participatory Action Research. Paper. Dipresentasikan pada Pertemuan Penelitian Partisipatoris Dunia Ketiga. Managua, Nicaragua, 3-9 September 1989.

Reason, P. \& Heron, J. 1995. Co-operative Inquiry. Dalam J.A. Smith, R. Harre \& L. V. Langenhove (Eds.). Rethinking Methods in Psychology. London: Sage Publications.
Uzzel, D. 1995. Ethnographic and Action Research. Dalam G.M. Breakwell, S. Hammond, \& C. Fife-Schaw (Eds.) Research Methods in Psychology. London: Sage Publications.

Smith, J.A. Harre, R. \& Langenhove, L.V. 1995. Introduction. Dalam J.A. Smith, R. Harre \& L.V. Langenhove (Eds.) Rothinking Method's in Psychology. London: Sage Publications.

Smith, B. \& Speedy, R. 1993. Critical Approach. Dalam H.C. Connole, B. Smith, R. Wiseman, R (Eds.). Research Moth odolagy. Issues and Methods in $\mathrm{Re}$ search. Geelong: Deakin University.

$+t+$ 